Available online at www.refaad.com

VMPH 2(1); 2021: 8-16

Research Article

Veterinary Medicine and Public Health Journal (VMPH)

Journal Homepage: https://www.refaad.com/views/vmph/home.aspx

www.refaad.com

ISSN : 2707-7195(Online) 2707-7187(Print)

\title{
Anticoccidial potentials of methanol leaf extract of Lannea Schimperi in experimentally induced Eimeria tenella infection in broiler chickens
}

\author{
Mohammed, Balarabe Rabiu*a, Hudu Garba Mikail b , Ibrahim Anka Abubakar ${ }^{c}$, Magaji Yusuf ${ }^{d}$, Garba \\ Hussain $e$ \\ a Department of Veterinary Parasitology and Entomology, Faculty of Veterinary Medicine, University of Abuja, P.M.B 117, \\ Federal Capital Territory, Abuja, Nigeria. balarabemohammed161@yahoo.co.uk \\ b Department of Veterinary Pharmacology and Toxicology, Faculty of Veterinary Medicine, University of Abuja, P.M.B 117, \\ Federal Capital Territory, Abuja, Nigeria. mghudu@yahoo.com \\ c Department of Veterinary Parasitology and Entomology, Faculty of Veterinary Medicine, Usman Danfodiyo University \\ Sokoto, Nigeria. ankaone@yahoo.com \\ d Department of Veterinary Parasitology and Entomology, Faculty of Veterinary Medicine, Ahmadu Bello University Zaria, \\ Nigeria. magajiyusuf@yahoo.com \\ e Department of Veterinary Parasitology and Entomology, Faculty of Veterinary Medicine, Ahmadu Bello University Zaria, \\ Nigeria. garbahussain@yahoo.com
}

* Corresponding author: Mohammed, Balarabe Rabiu. Email: balarabemohammed161@yahoo.co.uk

How to cite this article: Mohammed, Balarabe R. et al., Anticoccidial Potentials of Methanol Leaf Extract of Lannea schimperi in Experimentally Induced Eimeria tenella Infection in Broiler Chickens. Veterinary Medicine and Public Health Journal 2(1); 2021: 8-16.

DOI: https://doi.org/10.31559/vmph2021.2.1.2 Received Date: 4/8/2020 Revised Date: 13/9/2020 Accepted Date: 30/9/2020

\section{Abstract}

Coccidiosis is caused in chickens by the genus Eimeria spp, and is considered as one of the dominant poultry diseases worldwide. For decades, anticoccidial products have been used for the successful control of this disease. However, long term use of these products has led to the development of resistance. The current study therefore sought to investigate the anticoccidial activity of the methanol leaf extract of Lannea schimperi on experimentally induced Eimeria tenella (E. tenella) infection in broiler chickens in an attempt to provide good alternative therapy due to increasing resistance to the conventional anticoccidial agents. Seven groups (A-G) of 4 birds were used for the experiment and five groups (A-E) were orally inoculated with $1.0 \times 10^{3}$ sporulated oocysts of $E$. tenella. Groups A, B and C were treated with 25,50 and $100 \mathrm{mg} / \mathrm{kg}$ body weight of L. schimperi methanolic leaf extract respectively and Group D was treated with $1.5 \mathrm{mg} / \mathrm{ml}$ of amprolium, group E served as negative control. Groups F and G were the uninfected neutral control and were treated with 25 and $100 \mathrm{mg} / \mathrm{ml}$ of L. schimperi methanol leaf extract respectively without being infected with $E$. tenella oocysts. Findings revealed dose dependent anticoccidial effect, with highest concentration of $100 \mathrm{mg} / \mathrm{ml}$ giving more activity than 50 and $25 \mathrm{mg} / \mathrm{ml}$ of the plant extract. Significant decrease $(\mathrm{P} \leq 0.05)$ in the number of both schizonts and merozoites in the groups (A, B, C, F and G) treated with L. schimperi methanol leaf extract were observed. Large number of schizonts and merozoites were observed in the infected untreated group compared to the treated groups. Significant changes were also seen in the number of circulating eosinophils and lymphocytes. Insignificant changes $(\mathrm{P}>0.05)$ in body weight gain were recorded; however, significant increase $(\mathrm{P} \leq$ 0.05 ) in the intestinal mucus secretion was recorded in the amprolium treated group. These findings suggest that the methanolic leaf extract of L. schimperi possess anticoccidial activity that may warrant further investigation.

Keywords: Anticoccidia; broiler chicken; Eimeria tenella; methanol leaf extract; Lannea schimperi. 


\section{Introduction}

Coccidiosis is a disease caused by gastrointestinal protozoan parasites in the genus Eimeria. In the poultry industry coccidiosis is responsible for significant economic loss (Chandrakesan et al. 2009; Haritova et al. 2013; Babatunde et al. 2017; Mohammed et al. 2017). The disease is characterized by enteritis and is transmitted feco-oral when the susceptible host chicken ingests oocysts that were passed in the faeces of an infected bird (Shivaramaiah et al. 2014; Mohammed and Sunday 2015). Eimeria tenella is typically the most pathogenic species infecting broiler chickens and usually infects the mucosa of the caecum (Naidoo et al. 2008; Abbas et al. 2011). Mucosal surfaces are the most common route used by pathogens to enter the body and are covered by a continuously secreted mucus layer that protects the epithelial surface (Quintana-Hayashi et al. 2018).

Vaccines, anticoccidial chemicals and natural products are among the current approaches to constrain avian coccidiosis (Chapman et al. 2010). Although the strategy is successful and costeffective, there is the need for alternative control strategies due to increasing drug resistance and the need for natural drug free meat to address public health concerns (Chapman et al. 2010).

Anticoccidial drugs used in chicken feed serve as the major control of coccidial infection (Guo et al. 2007). However, there has been continues increase in the emergence of strains resistant to current approaches (EFSA 2017). Plants and their extracts are increasingly being used as a natural treatment for control and therapy (Dinan et al. 2007).

The plant Lannea schimperi is used in folk medicine for the treatment of a number of illnesses. The leaf, fruit, bark and root have potential pharmacological activities that include antimicrobial, antitussive, antidiarrheal, antidiabetic, antiemetic and antifungal activities in an animal model (Neuwinger 2000). Here, we sought to investigate the anticoccidial activity of the methanol leaf extract of $L$. schimperi on experimentally induced $E$. tenella infection in broiler chickens.

\section{Materials and Methods}

\section{Collection, identification, processing and extraction of the plant material:}

Freshly collected plants were identified at the National Research Institute of Chemical Technology (NARICT) Zaria, Kaduna State, Nigeria. The leaves were separated from the branchlets, cleaned with tap water, air dried and pounded with pestle and mortar into fine particles. The grinded fine plant material was weighed and extracted by maceration using absolute methanol for 72 hours. The leaf extract was filtered and evaporated to dryness and; the dried extract was kept in capped bottles at $4{ }^{\circ} \mathrm{C}$ until needed.

\section{Eimeria tenella isolate:}

Eimeria tenella oocysts were isolated using flotation (Soulsby 1986) from the caeca of naturally infected chicks and sporulated in $2.5 \%$ potassium dichromate solution at room temperature. The sporulated oocysts were used for testing the efficacy of different concentrations of the plant extract on experimental infections in broiler chickens.

\section{Ethical statement:}

The study was approved by the University of Abuja Ethical Committee on Animal Use (UAECAU/2018/0002) and was conducted in accordance with the approved protocol.

\section{Experimental infection of chicken groups:}

Two-week-old chicks $(\mathrm{N}=28)$ with mean body weight of $0.400 \mathrm{Kg}$ were used in this study. The chickens were divided equally into 7 groups (A to $G$ ). Those in groups A, B, C, D, and E were infected by oral administration of $1 \mathrm{ml}$ containing $1.0 \times 10^{3}$ sporulated oocysts of Eimeria tenella. Groups F and $\mathrm{G}$ remained uninfected.

\section{Treatment of experimentally infected chickens':}

The chickens were infected by oral administration of $1 \mathrm{ml}$ containing $1 \times 10^{3}$ sporulated $E$. tenella oocysts and randomly placed into 5 treatment groups $(\mathrm{N}=4)$. Three groups $(\mathrm{A}, \mathrm{B}, \mathrm{C})$ were treated with 25,50 and $100 \mathrm{mg} / \mathrm{kg}$ body weight of L. schimperi methanol leaf extract, respectively. One group (D) was treated with amprolium (KEPRO B.V; Holland) at the dose of 1.5 $\mathrm{mg} / \mathrm{ml}$, and one group (E) was infected but not treated. Two groups $(F, G)$ were only treated with 25 and $100 \mathrm{mg} / \mathrm{ml}$ of L. schimperimethanol leaf extract, respectively without being infected with $E$. tenella oocysts. Faecal samples were collected on days 0, 3, 5 and 7 and a fecal egg count (oocysts/g of feces) was determined using the McMaster technique as described by Long et al. (1976) before and after infection. No exposure to any anticoccidial agent was made prior to infection.

\section{Haematology:}

Blood samples were collected through the wing vein into EDTA bottles on days 0 (before inoculation), and days 3,5 and 7 post inoculation. Differential blood counts were performed manually by analysing 200 leukocytes in blood smears. In order to trace the potential formation of the anaemia, packed cell volume (PCV) and the concentration of haemoglobin $(\mathrm{Hb})$ were determined according to standard procedures as described by Jain 1993.

\section{Determination of body weight gain:}

Body weights of the chickens were taken on day 0,4 and 7 using digital weighing scale. 


\section{Intestinal smears:}

Intestinal mucosal smears were taken from the caeca at the end of the experiment; the smears were stained with Giemsa stain. Schizonts and merozoites were viewed using oil immersion at x 1000 magnification.

\section{Evaluation of intestinal mucus:}

Mucus samples were collected from the intestine, from the central segment of the duodenum and Meckel's diverticulum (jejunum), up to the ileocaecal junction (ileum) and caudal part of the caecum (Major et al. 2011).

\section{Data management and analysis:}

Data obtained from the study were expressed as mean plus/minus standard error of the mean (Mean \pm SEM). The data were also analysed using one-way analysis of variance (ANOVA) followed by Tukey post-hoc with the aid of SPSS statistical software (version 4.0). Data from the intestinal mucus secretion were analysed using the Independent Sample T-Test. Values $\leq 0.05$ were statistically considered significant.

\section{Results}

Significant decrease $(\mathrm{P} \leq 0.05)$ in number of oocysts was recorded between the groups treated with the different concentrations of the plant leaf extract and the infected untreated negative control (Figure 1).

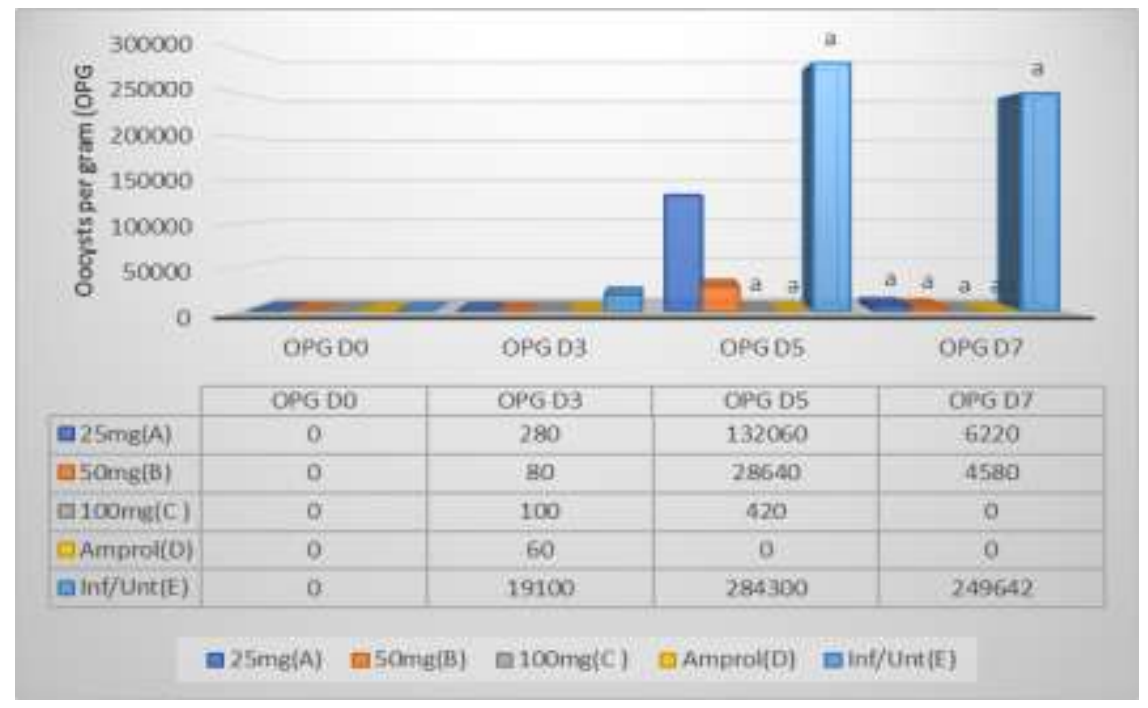

Figure (1): Effect of methanol leaf extract of L. schimperi treatment on faecal oocysts per gram (OPG) counts on broiler chickens infected with E. tenella. Data are presented as mean \pm SEM.

Key:

$\mathrm{a}=$ Significant difference $(\mathrm{P} \leq 0.05)$ between group $\mathrm{E}$ and groups $\mathrm{A}, \mathrm{B}, \mathrm{C}$ and $\mathrm{D}$

Group A $=25 \mathrm{mg} / \mathrm{ml}$ of L. schimperi extract used to treat and infect and treat chickens

Group B $=50 \mathrm{mg} / \mathrm{ml}$ of $L$. schimperi extract used to treat and infect and treat chickens

Group C $=100 \mathrm{mg} / \mathrm{ml}$ of L. schimperi extract used to treat and infect and treat chickens

Group $\mathrm{D}=1.5 \mathrm{mg} / \mathrm{ml}$ of amprolium used for treatment but uninfected

Group $\mathrm{E}=$ Treatment but no infection

OPG $=$ Oocysts per gram

DPI = Days post inoculation

$\mathrm{D} \quad=$ Day

Large number of schizonts and merozoites were recorded in the infected untreated group compared to other experimental groups.
There was a significant increase in the number of heterophils between the negative control and other experimental groups (Figure 2). 


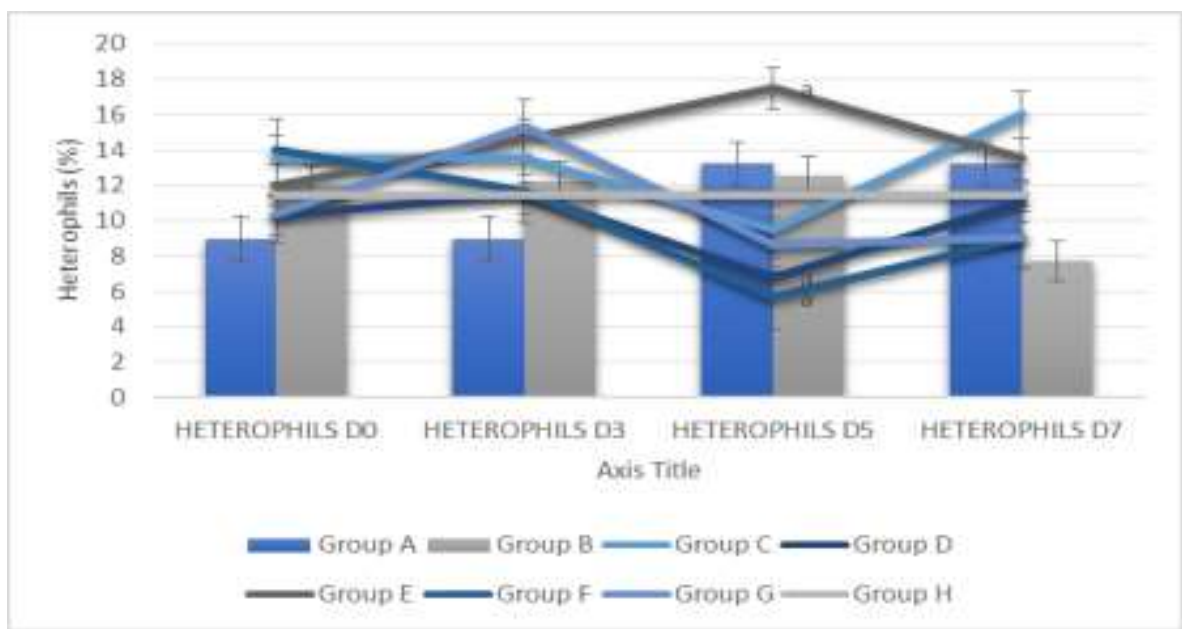

Figure (2): Effect of methanol leaf extract of L. schimperi treatment on number of circulating heterophils of broiler chickens infected with $E$. tenella. Data are presented as mean \pm SEM.

Key: a:Indicates significant increase $(P>0.05)$ in number of circulating heterophils in group 5 compared to groups 4 and $6 ; \mathrm{group} \mathrm{A:25} \mathrm{mg/ml}$ of L. schimperi extract used for infection and treatment of chickens; group B : $50 \mathrm{mg} / \mathrm{ml}$ of L. schimperi extract used for infection and treatment of chickens; group C : $100 \mathrm{mg} / \mathrm{ml}$ of L. schimperi extract used for infection and treatment of chickens; group D : $1.5 \mathrm{mg} / \mathrm{ml} \mathrm{of}$ amprolium used for treatment but no infection of chickens; group E : Infection in chickens but treatment; group F : $100 \mathrm{mg} / \mathrm{ml}$ of L. schimperi extract used for treatment of chickens but no infection; group G: $25 \mathrm{mg} / \mathrm{ml}$ of L. schimperi extract used for treatment of chickens but no infection; D : Day

There was a significant increase $(P \leq 0.05)$ in number of eosinophils in the group treated with amprolium (positive control) compared to negative

control (infected untreated) and groups only treated with 25 and $100 \mathrm{mg} / \mathrm{ml}$ of the plant extract, respectively (Figure 3).

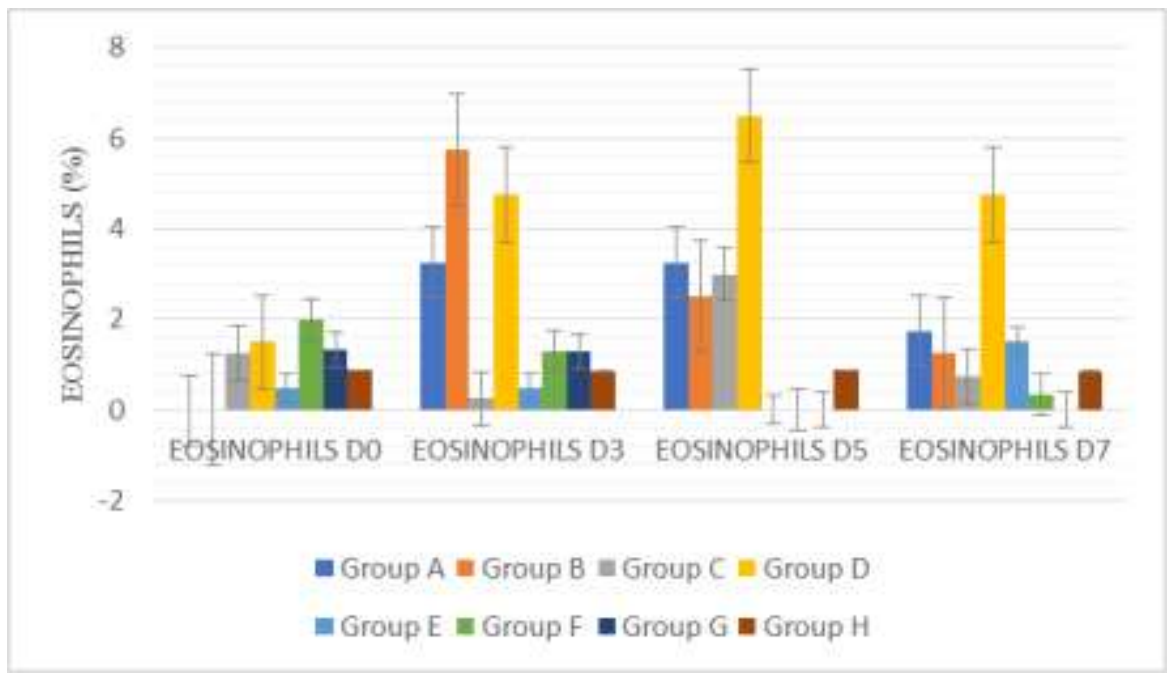

Figure (3): Effect of methanol leaf extract of L. schimperi treatment on number of circulating eosinophils of broiler chickens infected with E. tenella. Data are presented as mean \pm SEM.

Key: a: Indicates significant increase $(\mathrm{P}>0.05)$ in number of circulating eosinophils in group 4; group A : $25 \mathrm{mg} / \mathrm{ml}$ of L. schimperi extract used for infection and treatment in chickens; group B : $50 \mathrm{mg} / \mathrm{ml}$ of $L$. schimperi extract used for infection and treatment in chickens; group C : $100 \mathrm{mg} / \mathrm{ml}$ of L. schimperi extract used for infection and treatment in chickens; group D : $1.5 \mathrm{mg} / \mathrm{ml}$ of amprolium used for treatment but no infection in chickens; group E : Infected untreated; group F : $100 \mathrm{mg} / \mathrm{ml}$ of $L$. schimperi extract used for treatment but with no infection in chickens; group G : $25 \mathrm{mg} / \mathrm{ml}$ of $L$. schimperi extract used for treatment but no infection in chickens; D : Day

There was a significant increase $(P \leq 0.05)$ in the total number of white blood cells in group treated with the plant extract (Figure 4). 


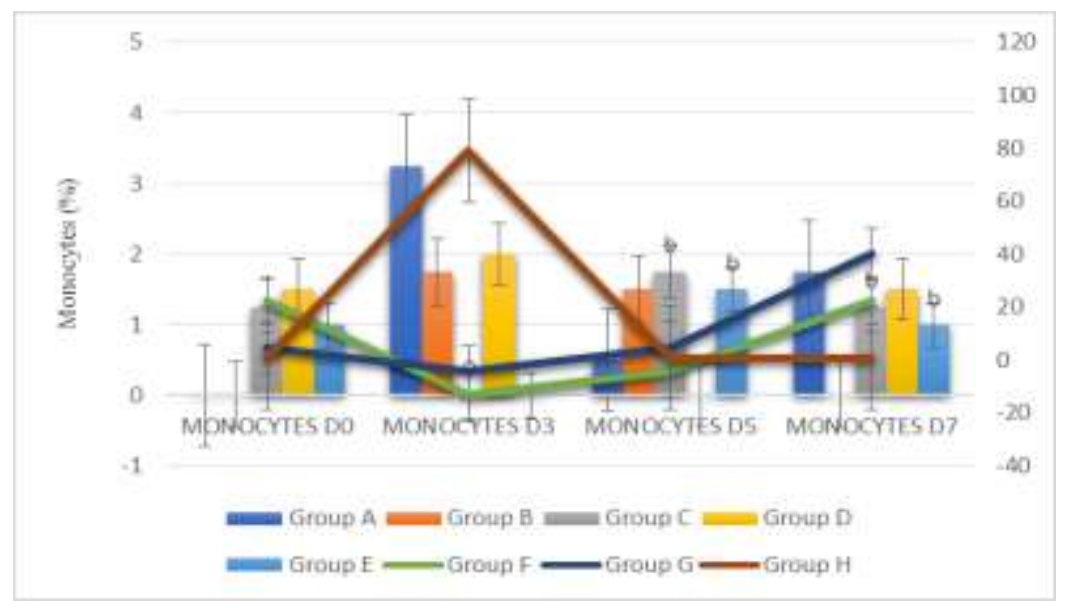

Figure (4): Effect of methanol leaf extract of L. schimperi treatment on total number of circulating white blood cell (TWBC) of broiler chickens infected with E. tenella. Data are presented as mean \pm SEM.

Key: a:Indicates significant difference (P > 0.05) in TWBC between group 5 and groups 2,4 and 6 ; group A : $25 \mathrm{mg} / \mathrm{ml}$ of L. schimperi extract used for infection and treatment in chickens; group B : $50 \mathrm{mg} / \mathrm{ml}$ of $L$. schimperi extract used for infection and treatment in chickens; group C : $100 \mathrm{mg} / \mathrm{ml}$ of L. schimperi extract used for infection and treatment in chickens ; group D : $1.5 \mathrm{mg} / \mathrm{ml}$ of amprolium used for treatment but no infection in chickens; group E : Infection but no treatment; group F : $100 \mathrm{mg} / \mathrm{ml}$ of $L$. schimperi extract used for treatment but no infection in chickens; group G : $25 \mathrm{mg} / \mathrm{ml}$ of L. schimperi extract used for treatment but no infection in chickens; D : Day.

There was a significant increase $(\mathrm{P} \leq 0.05)$ in $\mathrm{mg} / \mathrm{ml}$ (Figure 5) and the group not infected but plasma protein in the positive control group treated with $25 \mathrm{mg} / \mathrm{ml}$ of the plant leaf extract compared to group infected and treated with 50 (Figure 6).

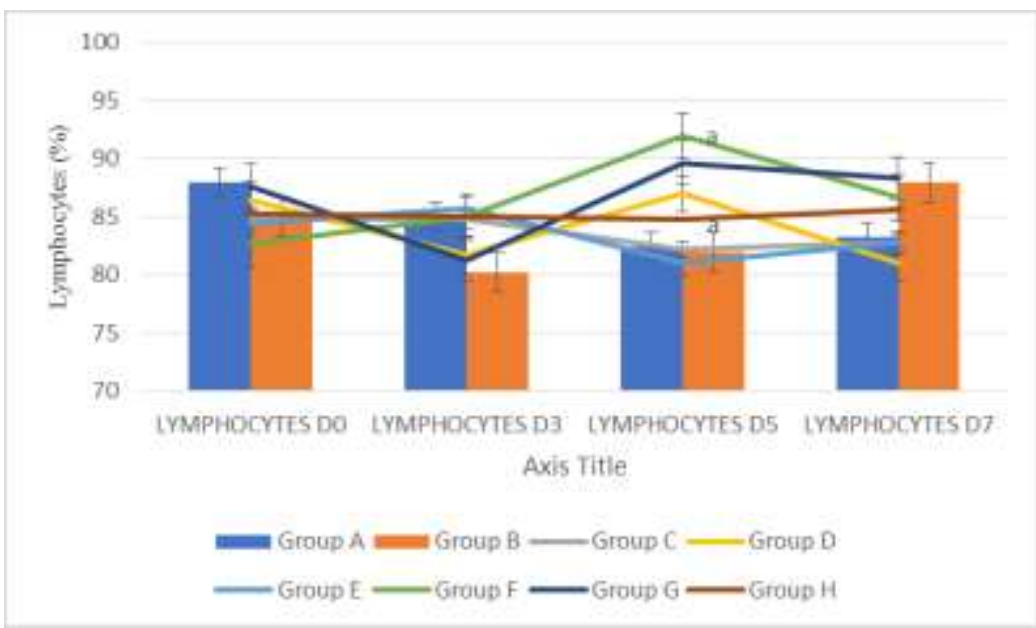

Figure (5): Effect of methanol leaf extract of L. schimperi treatment on number of lymphocytes of broiler chickens infected with E. tenella. Data are presented as mean \pm SEM.

Key: a :Indicates significant difference $(\mathrm{P}>0.05)$ in number of circulating lymphocytes between group 5 and 6; group A : $25 \mathrm{mg} / \mathrm{ml}$ of $L$. schimperi extract used for infection and treatment of chickens; group B : $50 \mathrm{mg} / \mathrm{ml}$ of $L$. schimperi extract used for infection and treatment of chickens; group C : $100 \mathrm{mg} / \mathrm{ml}$ of $L$. schimperi extract used for infection and treatment of chickens; group D : $1.5 \mathrm{mg} / \mathrm{ml}$ of amprolium used for treatment but no infection in chickens; group E : Infection but no treatment; group F : $100 \mathrm{mg} / \mathrm{ml}$ of L. schimperi extract used for treatment but no infection in chickens; group G : $25 \mathrm{mg} / \mathrm{ml}$ of L. schimperi extract used for treatment but no infection; D : Day. 


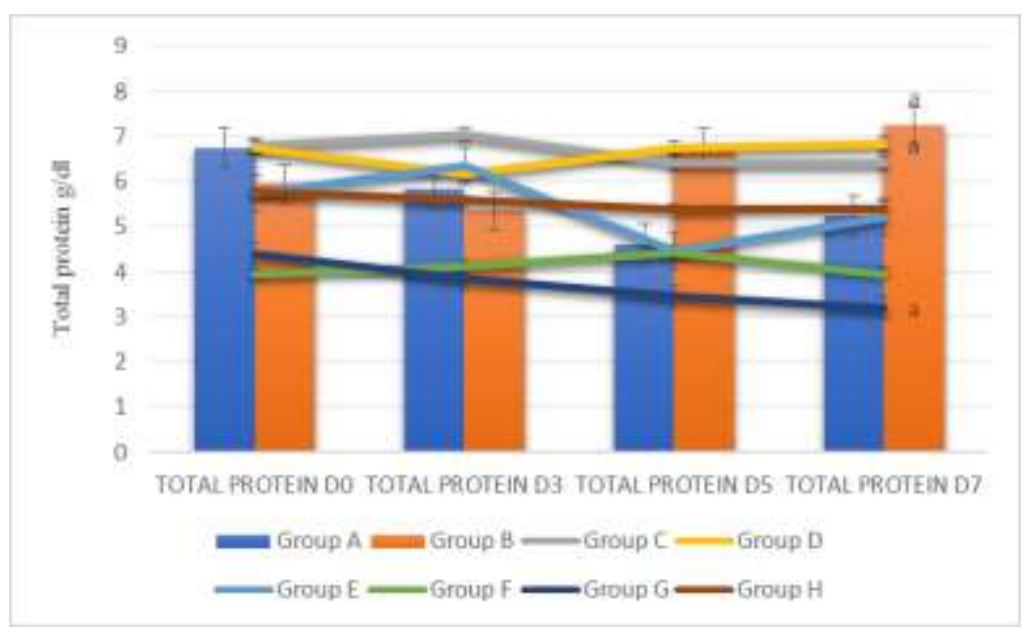

Figure (6): Effect of methanol leaf extract of L. schimperi treatment on total plasma protein of broiler chickens infected with $E$. tenella. Data are presented as mean \pm SEM.

Key: a = Indicates significant difference $(\mathrm{P}>0.05)$ in total plasma protein between group 7 and groups 4 and 2;group A : Infected and treated with $25 \mathrm{mg} / \mathrm{ml}$ of L. schimperi extract; group B : Infected and treated with $50 \mathrm{mg} / \mathrm{ml}$ of L. schimperi extract; group C : Infected and treated with $100 \mathrm{mg} / \mathrm{ml}$ of $L$. schimperi extract; group D : Uninfected and treated with $1.5 \mathrm{mg} / \mathrm{ml}$ of amprolium; group E : Infected untreated; group F: Uninfected and treated with $100 \mathrm{mg} / \mathrm{ml}$ of L. schimperi extract; group G : Uninfected and treated with $25 \mathrm{mg} / \mathrm{ml}$ of L. schimperi extract; D : Day.

Changes in body weight recorded were not weight was recorded in the positive control group (Figure 8). significant ( $\mathrm{P}>0.05)$ (Figure 7), however, significant increase $(\mathrm{P} \leq 0.05)$ in intestinal mucus

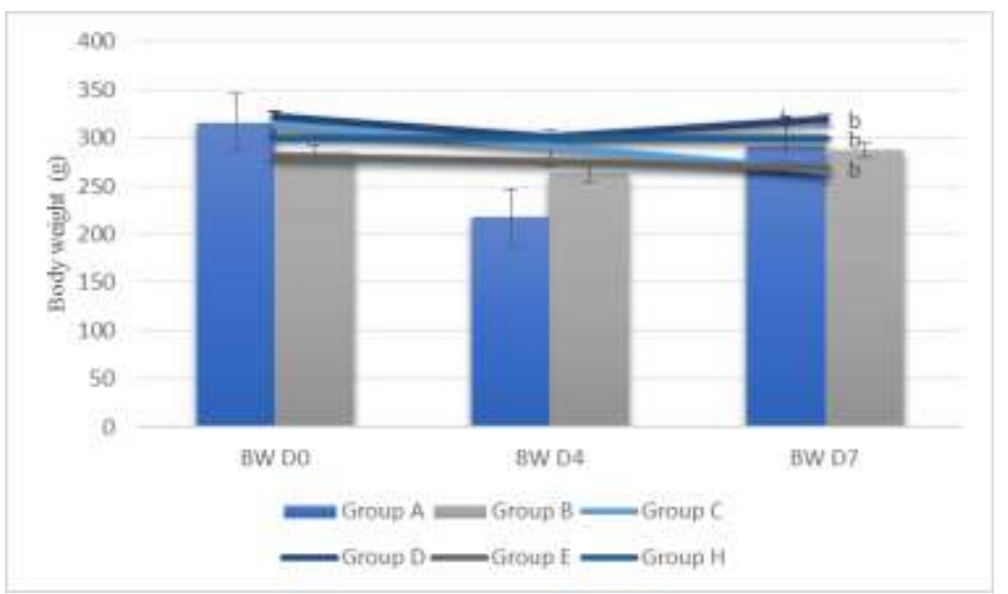

Figure (7): Effect of methanol leaf extract of L. schimperi treatment on body weight gain of broiler chickens infected with $E$. tenella. Data are presented as mean \pm SEM.

Key: b: Indicates insignificant difference $(P>0.05)$ in total body weight between various experimental groups; group A: Infected and treated with $25 \mathrm{mg} / \mathrm{ml}$ of $L$. schimperi extract; group B: Infected and treated with $50 \mathrm{mg} / \mathrm{ml}$ of $L$. schimperi extract; group C: Infected and treated with $100 \mathrm{mg} / \mathrm{ml}$ of L. schimperi extract; group D: Uninfected and treated with $1.5 \mathrm{mg} / \mathrm{ml}$ of amprolium.

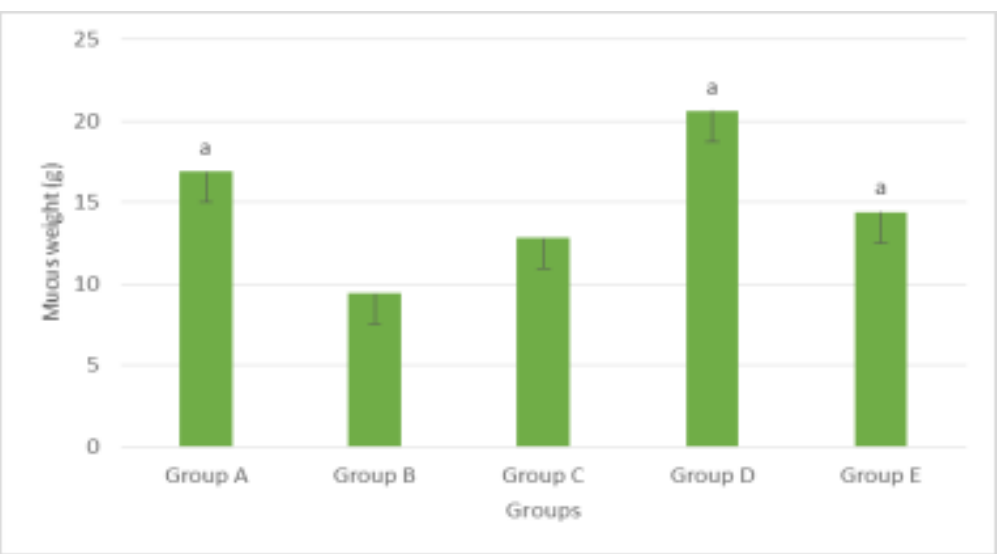

Figure (8): Effect of methanol leaf extract of L. schimperi treatment on intestinal mucus weight of broiler chickens infected with E. tenella. Data are presented as mean \pm SEM.

Key: a $=$ Indicates significant difference $(P>0.05)$ in intestinal mucus weight between group 5 and groups 4 and 1; group A : Infected and treated with $25 \mathrm{mg} / \mathrm{ml}$ of L. schimperi extract; group B : Infected and treated with $50 \mathrm{mg} / \mathrm{ml} \mathrm{of} \mathrm{L.} \mathrm{schimperi} \mathrm{extract;} \mathrm{group} \mathrm{C} \mathrm{:} \mathrm{Infected} \mathrm{and}$ treated with $100 \mathrm{mg} / \mathrm{ml}$ of L. schimperi extract; group D : Uninfected and treated with $1.5 \mathrm{mg} / \mathrm{ml}$ of amprolium. 
Mild presence of schizonts were recorded in the amprolium and extract $(100 \mathrm{mg} / \mathrm{ml})$ treated groups, moderate presence of both schizonts and merozoites were recorded in the groups treated with 25 and 50 $\mathrm{mg} / \mathrm{ml}$ of the extract. Large presence of both schizonts and merozoites were recorded in the infected untreated group (Table 1).

Table (1): Showing intestinal smear of the infected chicken groups

\begin{tabular}{|c|c|c|}
\hline Experimental groups & Animals sacrificed & Intestinal regions??? Caecum \\
\hline \multirow[t]{2}{*}{ Group A (25 mg/ml L. schimperi) } & $\mathrm{A} 1$ & Schizonts $(++)$, merozoite $(+)$ \\
\hline & $\mathrm{A} 2$ & Schizonts $(++)$, merozoite $(+)$ \\
\hline \multirow[t]{2}{*}{ Group B (50 mg/ml L. schimperi) } & B1 & Schizonts $(++)$ \\
\hline & B2 & Schizonts $(++)$ \\
\hline \multirow[t]{2}{*}{ Group C (100 mg/ml L. schimperi) } & $\mathrm{C} 1$ & Schizonts (+) \\
\hline & $\mathrm{C} 2$ & Schizonts $(+)$ \\
\hline \multirow[t]{2}{*}{ Group D (Amprolium 1.5 mg/ml) } & D1 & Schizonts $(+)$ \\
\hline & D2 & Schizonts $(+)$ \\
\hline \multirow[t]{2}{*}{ Group E (Infected untreated) } & E1 & Schizonts $(+++)$, merozoites $(+++)$ \\
\hline & E2 & Schizonts $(+++)$, merozoites $(+++)$ \\
\hline
\end{tabular}

+ Mild presence; ++ Moderate presence; +++Large presence

\section{Discussions}

The most common and pathogenic Eimeria species is Eimeria tenella, the major cause of coccidiosis in chickens (Abdel-Wasae Alashwal 2014). Coccidiosis is associated with oocysts shedding (Major et al. 2011), impaired feed conversion and reduced growth rate leading to poor performance and mortality of broiler chickens (Chandrakesan et al. 2009). Shedding of E. tenella oocysts in this experiment by the inoculated broiler chickens agrees with reports of Abdel-Wasae and Alashwal 2014 and Abdul -Wasae et al. 2017 that infected chickens mostly shed coccidian oocysts in their faeces during the disease process. However, there was a remarkable decrease in faecal oocysts per gram count to zero before day 7 post inoculation in the groups treated with amprolium and 100 $\mathrm{mg} / \mathrm{ml}$ of L. schimperi leaf extract. Both mature/immature schizonts and merozoites (developmental stages of the parasite) were seen in the intestinal smear of infected untreated chickens compared to the extract and amprolium treated groups.

These findings support the report of Mikail et al. (2016) that methanol leaf extract of L. schimperi possess anticoccidial activity in vitro. It further suggests that the plant leaf extract has a dose dependent anticoccidial effect with the highest concentration of $100 \mathrm{mg} / \mathrm{ml}$ giving more activity that 50 and $25 \mathrm{mg} / \mathrm{ml}$ of the plant extract.

Number of circulating heterophils increase with acute or chronic inflammatory disease conditions (Irizaary-Rovira 2004), thus, increase heterophilia in the infected untreated group is an indication of inflammatory condition due to invasion of intestinal mucosa of infected chickens by schizonts and merozoites. Similarly, decrease in the number of heterophils in the infected and treated groups indicates decrease invasion of intestinal mucosa by developmental stages of the coccidian parasite and recovery from the disease process.

Loss of blood and fluids in faeces of infected animals is caused by damages to the gastrointestinal tract by the offending coccidian parasites (IrizaaryRovira 2004; Ogbe et al. 2010) which is associated with decrease in packed cell volume (PCV), total red blood cells (TRBC) count and haemoglobin concentration (Hb), thus, leading to anaemia. In the current study, insignificant changes were recorded in PCV, TRBC and $\mathrm{Hb}$ indicating that the disease condition was a moderate one, which could be associated with loss dose of parasite inoculated to the chickens. Similarly, insignificant changes in body weight of infected animals are also another indicator that the disease process was moderate. The increase in plasma protein in amprolium and $50 \mathrm{mg} / \mathrm{ml}$ treated groups could be linked to improved immunity as plasma protein form part of immune proteins. "The mucus layer is the first barrier the pathogen must overcome for successful colonization, and is mainly composed of densely glycosylated proteins called mucins" (Quintana-Hayashi et al. 2018). Thus, the increase in mucus secretion in the group treated with amprolium suggests increase protection of intestinal mucosal colonization by the coccidian parasites. However, intestinal mucus secretion inversely increases in the groups treated with the plant leaf extract with significant in lower dose than the higher dose.

Conclusively, the present study suggests that methanol leaf extract of L. schimperi possess dose dependent anticoccidial activity. This should be 
subjected to detailed pharmacological, phytochemical and toxicological evaluations aimed at correlating its medicinal uses and pharmacological activities. Consequently, $L$. schimperi extract might be a potential avian anticoccidial agent.

Acknowledgements: We will like to acknowledge the effort of Professor M.Y. Fatihu and Mr Yunusa Muhammad of the Department of Veterinary Pathology, Ahmadu Bello University, Zaria, Nigeria toward the success of this work.

Conflict of interest: The authors declare that they have no conflicting interest.

Ethical approval: All ethics applicable of the University of Abuja guidelines for the care and use of animals were followed.

\section{References}

[1] Abbas R.Z., Munawar S.H., Manzoor Z., Iqbal Z., Khan M.N., Saleemi M.K., Zia M.A. \& Yousaf A. (2011). "Anticoccidial effects of acetic acid on performance and pathogenic parameters in broiler chickens challenged with Eimeria tenella". Pesqui Vet Brasil 31(2): 99-103. https://doi.org/10.1590/s0100-736x2011000200001.

[2] Abdel-Wasae B. M. \& Alashwal M.A. (2014). "Study the efficacy of Aloe vacillans compared with Amprolium drug in broiler chickens experimentally infected with Eimeria tenella in Taiz-Yemen". Univ Aden J Nat Appl Sc 18 (1): 91-104.

[3] Abdul -Wasae B.M., Alashwal M.A.S. \& El-Essy M. (2017). "A preliminary study on possible effect of Plectranthus spp. extract on histopathology and performance of Broilers chicken infected by Eimeria tenella in Taiz city", Yemen, Egyptian Poult $\begin{array}{llll}\text { Sci J 37(3): } & \text { 761-777. }\end{array}$ https://doi.org/10.21608/epsj.2017.7575.

[4] Babatunde S.M., Mohammed B.R., Simon M.K. \& Agbede R.I. (2017). "Coccidial Infection in Freerange and Intensively Managed Chickens in Gwagwalada Area Council, Abuja-Nigeria, SubSaharan Africa". Alexandria J Vet Sci 51(2): 183188. https://doi.org/10.5455/ajvs.220092.

[5] Chandrakesan P., Muralidharan K., Dinesh Kumar V., Ponnudurai G., Jeyagopal H.T., Senthil V. N. \& Rani K. (2009). "Efficacy of an herbal complex against caecal coccidiosis in broiler chickens". Vet Arhiv, 79(2): 199-203.

[6] Chapman H.D., Jeffers T.K. \& Williams R.B. (2010). "Forty years of monensin for the control of coccidiosis in poultry". Poult Sci, 189(9): 1788-801. https://doi.org/10.3382/ps.2010-00931.

[7] Dinan L., Savchenko T. \& Whiting P. (2001). "On the distribution of phytoecdysteroids in plants". Cell Mol Life Sci CMLS, 58(8): 1121-32. https://doi.org/10.1007/pl00000926.

[8] European Food Safety Authority; European Centre for Disease Prevention and Control the European union summary report on antimicrobial resistance in zoonotic and indicator bacteria from humans, animals and food in 2015, EFSA J. (15) (2017), 469.
[9] Guo F.C., Suo X., Zhang G.Z. \& Shen J.Z. (2007). "Efficacy of decoquinate against drug sensitive laboratory strains of Eimeria tenella and field isolates of Eimeria spp. in broiler chickens in China". Vet Parasitol 147(3-4): 239-45. https://doi.org/10.1016/j.vetpar.2007.04.002.

[10] Haritova A.M., Lashev L.D. \& Koinarski V.C. (2013). "Sulfachloropyrazine disposition in Eimeria tenella infected chickens". Vet Arhiv 83(2): 211-22.

[11] Irizaary-Rovira A.R. (2004). "Avian and reptilian clinical pathology (Avian haematology and biochemical analysis)", Section XI, In R.L. Cowell, (ed.). Veterinary clinical pathology secrets. Elsevier Inc. St. Louis, MO, USA., 282-313.

[12] Jain N.C. (1993). "Essentials of Veterinary Haematology". Lea \& Febiger Publication, Philadelphia, 389-396

[13] Lillehoj H.S., Ding X., Dalloul R.A., Sato T., Yasuda A. \& Lillehoj E.P. (2005). "Embryo vaccination against Eimeria tenella and E. acervulina infections using recombinant proteins and cytokine adjuvants". J Parasitol 91(3): 666-73. https://doi.org/10.1645/ge3476.

[14] Long P.L., Millard B.J., Joyner L.P. \&Norton C.C. (1976). "A guide to laboratory techniques used in the study and diagnosis of avian coccidiosis". Folia Vet Lat 6(3): 201-17.

[15] Mohammed B. R., Simon M.K., Agbede R.I. \& Arzai A.H. (2017). "Coccidiosis of domestic pigeons (Columba livia domestica Gmelin, 1789) in Kano State, Nigeria". Annals of parasitology 63(3): 199203.

[16] Mohammed B.R. \& Sunday O.S. (2015). “An overview of the prevalence of avian coccidiosis in poultry production and its economic importance in Nigeria". Vet Res Int 3(3): 35-45.

[17] Major P., Revajová V., Levkut M., Ševčíková Z., Spišáková V., Faixová Z., Levkutová M., Kožárová I., Goldová M. \& Levkut M. (2011). "Intestinal mucin dynamic and leukocytic responses of chickens infected with Eimeria acervulina and fed oregano supplemented diet". Acta Vet Brno 80(2): 147-56. https://doi.org/10.2754/avb201180020147.

[18] Mikail H.G., Yusuf M. \& Hussain G. (2016). “In vitro anticoccidial activity of methanol leaves extract of Lannea schimperi against oocysts of Eimeria tenella". J Pharm Biol Sci (IOSR-JPBS) 11(Issue 3; Version II): 35-38.

[19] Naidoo V., McGaw L.J., Bisschop S.P., Duncan N. \& Eloff J.N. (2008). "The value of plant extracts with antioxidant activity in attenuating coccidiosis in broiler chickens". Vet Parasitol 153(3-4): 214-9. https://doi.org/10.1016/j.vetpar.2008.02.013.

[20] Neuwinger H.D. (2000). "African traditional medicine: a dictionary of plant use and applications". Medpharm Scientific, Stuttgart, Germany, 589.

[21] Ogbe A.O., Atawodi S.E., Abdu P.A., Oguntayo B.O. \& Dus N. (2010). "Oral treatment of Eimeria tenellainfected broilers using aqueous extract of wild mushroom (Ganoderma sp): Effect on haematological parameters and histopathology lesions". African J Biotech 9(52): 8923-7. 
[22] Prakashbabu B.C., Thenmozhi V., Limon G., Kundu K., Kumar S., Garg R., Clark E.L., Rao A.S., Raj D.G., Raman M. \& Banerjee P.S. (2017). "Eimeria species occurrence varies between geographic regions and poultry production systems and may influence parasite genetic diversity". Vet Parasitol, 233: 6272. https://doi.org/10.1016/j.vetpar.2016.12.003.

[23] Quintana-Hayashi M.P., Padra M., Padra J.T., Benktander J. \& Lindén S.K. (2018). "Mucuspathogen interactions in the gastrointestinal tract of farmed animals". Microorganisms 6(2): 55. https://doi.org/10.3390/microorganisms6020055.
[24] Shivaramaiah C., Barta J., Hernandez-Velasco X, Téllez G. \& Hargis B. (2014). "Coccidiosis: recent advancements in the immunobiology of Eimeria species, preventive measures, and the importance of vaccination as a control tool against these Apicomplexan parasites". Vet Med (Auckl), 5: 2334. https://doi.org/10.2147/vmrr.s57839.

[25] Soulsby E.J.L. (1986). Helminths, Arthropods and Protozoa of Domestic Animals ( $7^{\text {th }}$ edn) Beilliere Tindall, London, 231. 